\title{
THE EFFECT OF ADMINISTRATION OF ETHANOL EXTRACT FROM MUSA PARADISIACA L. (MPL) FRUIT ON THE CASPASE-3 MRNA GENE EXPRESSION IN RAT AMYLOID BETA INDUCED, AN ALZHEIMER'S DISEASE MODEL
}

\author{
EMMA KAMELIA ${ }^{1,3}$, ANDI ASADUL ISLAM ${ }^{2}$, MOCHAMMAD HATTA ${ }^{3 *}$, CAHYONO KAELAN ${ }^{4}$, ILHAMJAYA \\ PATELLONGI ${ }^{5}$
}

\begin{abstract}
${ }^{1}$ Dental Health Study Program, Tasikmalaya Health Polytechnic, West Java, Indonesia. ${ }^{2}$ Department of Neurosurgery, Medical Faculty, University of Hasanuddin, Makassar, Indonesia. ${ }^{3}$ Molecular Biology and Immunology Laboratory for Infection Diseases, Medical Faculty, University of Hasanuddin, Makassar, Indonesia. ${ }^{4}$ Department of Neurology, Medical Faculty, University of Hasanuddin Makassar, Indonesia. ${ }^{5}$ Department of Physiology, Medical Faculty, University of Hasanuddin, Makassar, Indonesia. Email: hattaram@yahoo.com
\end{abstract}

Received: 04 December 2017, Revised and Accepted: 11 January 2018

Objective: The objective of this study is to analyze caspase-3 mRNA gene expression in a Wistar rat model of Alzheimer's disease (AD) treated with Musa paradisiaca L. (MPL) ethanol extract or banana extract (BE)

Methods: MPL was evaluated for its effect on the caspase-3 mRNA gene expression of rat amyloid beta (A 3 ) induced, an AD model. Each model included twenty Wistar rats were randomized into five groups: K0, without $\mathrm{AD}$ induction and no BE; K1, AD induction and no BE; K2, $\mathrm{AD}$ induction+BE $250 \mathrm{mg} / \mathrm{kg}$ body weight (BW); K3, AD induction+BE $500 \mathrm{mg} / \mathrm{kg}$; and K4, AD induction+BE $1000 \mathrm{mg} / \mathrm{kg}$. AD induction was performed by A $\beta_{1-42} 0.2$ ug) injection at the intracerebroventricular area. mRNA caspase-3 level measurements were performed by real time-polymerase chain reaction.

Results: Paired t-test analysis showed no significant differences of caspase- 3 mRNA level before $A \beta$ induction among five groups ( $p>0.05$ ). At 6 weeks post- $A \beta$ induction, there was significantly increased caspase- 3 mRNA in all groups except $K 0(p<0.05)$. Notably, after 3 weeks of BE administration, caspase-3 mRNA expression was significantly decreased in all BE-treated groups; in the K1 placebo group, caspase- $3 \mathrm{mRNA}$ expression increased. The maximum decreased caspase-3 mRNA expression was in group K4 (-BE $1000 \mathrm{mg} / \mathrm{kg} \mathrm{BW}$ ), and the minimum was in group K2 (-BE $250 \mathrm{mg} / \mathrm{kg} \mathrm{BW}$ ).

Conclusion: The results revealed that the ethanolic extract of MPL fruit could decrease caspase-3 mRNA gene expression in AD rat

Keywords: Alzheimer's disease, Intracerebroventricularly, Amyloid beta, Caspase-3, Musa paradisiaca L.

(C) 2018 The Authors. Published by Innovare Academic Sciences Pvt Ltd. This is an open access article under the CC BY license (http://creativecommons. org/licenses/by/4. 0/) DOI: http://dx.doi.org/10.22159/ajpcr.2018.v11i4.24103

\section{INTRODUCTION}

Alzheimer's disease (AD) is an irreversible and progressive neurodegenerative disease, a form of dementia known globally, projected that, by 2050 , about 115 million people will be affected worldwide [1]. As the aging population increases, the number of patients with $\mathrm{AD}$ also increases, with a rate of $13 \%$ in older patients over 65 years old and $45 \%$ in the group aged over 85 years old [2]. The majority of $\mathrm{AD}$ cases occur in women compared with men, and the estimated risk for developing $\mathrm{AD}$ is about $20 \%$ for women and $10 \%$ for men age above 65 [3]. AD was initially discovered by German neural expert Alois Alzheimer in 1906, who found brain lesions that lead to dementia and they were highly associated with strokes, brain tumor, and degenerative diseases [4]. Several factors contribute to the progression of the disease including amyloid-beta $(A \beta)$ accumulation, neurofibrillary tangle formation, cholinergic deficit, oxidative stress, neuroinflammation, and apoptosis [5].

Apoptotic signaling is classified as proceeding by either an intrinsic pathway or an extrinsic pathway. The intrinsic apoptotic signaling is most often induced by the intracellular damage that leads to the mitochondrial release of cytochrome $c$ and the activation of intracellular cysteine proteases called caspases [6]. Extrinsic apoptotic signaling is initiated by stimulation of plasma membrane death receptors that initiate apoptosis by activation of caspase-8, and subsequent apoptotic signaling can proceed through the mitochondrial pathway or independently of mitochondria by caspase-8-mediated direct activation of caspase-3 [7]. Caspase- 3 acts as a caspase executor in the apoptosis process [8]. Caspase- 3 appears to be the major effector in neuronal apoptosis triggered by various stimuli. The first strong evidence supporting the specific role for this protease in neuronal apoptosis comes from studies on mice deficient in caspase- 3 in which brain development is profoundly altered [9]. Furthermore, $A \beta$ secretion decreased when there is an obstacle to its production in caspase- 3 caused by antioxidant and pramipexole [10]. The drugs designed to slow disease progression are available. Some medicinal herbs from plants may help to improve brain function, but scientific evidence to prove that they can treat $\mathrm{AD}$ is limited.

Commenges et al. found that an intake of flavonoids significantly reduced the risk of dementia [11]. In this research, caspase- 3 mRNA gene expression in an $\mathrm{AD}$ rat model induced by injection of $\mathrm{A} \beta$ for 6 weeks, which was treated with banana extract (BE)/Musa paradisiaca L. (MPL) for 3 weeks, was evaluated. The purpose of this study was to analyze the effect of BE (MPL) administration on the expression of the caspase- 3 mRNA gene in the Wistar rats model of AD, with the hypothesis that BE MPL administration for 3 weeks can decrease the expression of the caspase- 3 mRNA gene in Wistar rats which is in A $\beta$ induction for 6 weeks. $\mathrm{BE}$ referred to herein is $\mathrm{BE}$ or MPL which is extracted using ethanol.

\section{METHODS}

Materials

Experimental procedures were carried out in the Molecular Microbiology and Immunology Laboratory, Medical Faculty University 
of Hasanuddin, Makassar, Indonesia. This research was an experimental study in vivo pre- and post-design that was conducted from February to July 2016. The research has been approved by the Medical and Health Research Ethics Committee, Medical Faculty University of Hasanuddin, Makassar, Indonesia (Number: 391/H4.8.4.5.31/PP36-KOMTIK/2016).

\section{Animals}

\section{Animal preparation}

Twenty Wistar rats (2.5-3 months, 150-250 g) were maintenance at Animal Laboratory, Molecular Biology and Immunology Laboratory, Medical Faculty University of Hasanuddin, Makassar, Indonesia, for this study. The rats were randomly assigned to one of five groups $(=4$ in each group): The control ( $\mathrm{K} 0$ and $\mathrm{K} 1)$ and treatment groups (K2, K3, and K4). They were kept for 1 week for proper acclimatization before starting the experiment under the controlled condition of illumination ( $12 \mathrm{~h} \mathrm{light} / 12 \mathrm{~h}$ darkness) and temperature $23 \pm 2^{\circ} \mathrm{C}$. They were housed under ideal laboratory conditions and maintained on the standard pellet diet and water ad libitum throughout the experimental period. All procedures were by the internationally accepted guideline for experimental animal use and care of Animals Laboratory of the Molecular Microbiology and Immunology Laboratory, Medical Faculty University of Hasanuddin, Makassar.

\section{Experimental design}

In this study, total number of twenty Wistar rats were divided into following five groups having four rats in each group: $\mathrm{K} 0=$ no induction $\mathrm{AD}$ model and no BE MPL administration; K1=AD induction model without $\mathrm{BE}$ MPL administration (just given a placebo); $\mathrm{K} 2=\mathrm{AD}$ induction model with $250 \mathrm{mg} / \mathrm{kg}$ body weight (BW) BE MPL administration; K3=AD induction model with $500 \mathrm{mg} / \mathrm{kg}$ BW BE MPL administration; and $\mathrm{K} 4=\mathrm{AD}$ induction model with $1000 \mathrm{mg} / \mathrm{kg}$ BW BE MPL administration. Caspase-3 mRNA expression was assessed before AD induction, 6 weeks after AD induction, and 3 weeks post-BE MPL administration.

\section{Administration of MPL ethanol extract BE}

Banana fruits were obtained from a market in Bogor, West Java Province, Indonesia. The fruits were cut longitudinally into chips of about 5-10 mm thickness and then dried in an oven after which they were ground and added ethanol (95\%) to a conical flask and then shaken every $30 \mathrm{~min}$ (for $6 \mathrm{~h}$ ) and sterilized for $48 \mathrm{~h}$. The solution is then filtered using filter paper, ethanol added to the solution coming out of the colorless outer macerator (usually 5-6 times immersion) and then concentrated using a rotary evaporator until no more solvent, which drips on the rotary evaporator condenser. This is called solid dry extract and is used in this study. Three doses of the plantain flour were prepared: $250 \mathrm{mg} / \mathrm{kg} /$ day, $500 \mathrm{mg} / \mathrm{kg} /$ day, and $1000 \mathrm{mg} / \mathrm{kg} /$ day. The flour was dissolved in $2 \mathrm{ml}$ of double-distilled water, for easy administration. Banana MPL ethanol extract or BE was obtained by maceration methods at Balitro Bogor Agricultural Department Laboratory, West Java Province, Indonesia, and plant determination process from Central Biology Research, Bogor LIPI, West Java Province, Indonesia (Number: 147/IPH.1.02/lf.07/I/2016). Previous research by Ittiyavirah and Anurenj showed that a $200 \mathrm{mg} / \mathrm{kg}$ BW dose of MPL ethanol extract BE given over 21 days produced a significant effect on anti-stress activity [12]. In the study for this $\mathrm{AD}$, we increased the dose to $250 \mathrm{mg} / \mathrm{kg}$, and the BE used on $\mathrm{K} 2$ is $250 \mathrm{mg} / \mathrm{kg} \mathrm{BW}, \mathrm{K} 3500 \mathrm{mg} / \mathrm{kg}$ $\mathrm{BW}$, and $\mathrm{K} 41000 \mathrm{mg} / \mathrm{kg}$ BW for experimental analyses; treatments were given orally for 21 days ( 3 weeks) each day. While in $\mathrm{K} 1$ only given a placebo with the same time of administration is 3 weeks. Overall, both BE MPL and placebo were administered by mouth-feeding.

\section{Animal model}

In this research, we do advance preliminary research which was done to develop an animal model of the AD. To develop an AD model, we used a dose of $A \beta_{1-42}$ of $0.2 \mu \mathrm{g}$ injected in intracerebroventricular and observed the mice for 6 weeks, and $A \beta$ levels were measured using the SAA Mouse Elisa Kit. The $A D$ animal model was generated using $A \beta_{1-2}$ peptide from Abcam, code number.Ab120959 (Cambridge, MA, USA) [13], which is a reference modeling $\mathrm{AD}$ protocol.

\section{Blood collection}

Blood samples were collected at three time points: Day 0 before $A \beta$ injection (baseline); day 42 (week: 6), i.e., on the last day of post-AB induction observation or the day before the MPL intervention; and last is the day 63 , the last day of BE intervention which done in 21 days from day 42 (weeks: 9 , changes). Blood was taken from the tail vein using a $0.1 \mathrm{ml}$ hematocrit needle. The samples were centrifuged and were kept in a sterile tube at $-20^{\circ} \mathrm{C}$ until analyses.

\section{Real time-polymerase chain reaction (RT-PCR)}

The RT-PCR Method uses the Boom method, which has high sensitivity and specificity for disease diagnosis. In the extraction of DNA, the materials used are diatoms, L6 (lysis buffer), L2 (washing buffer), and TE (elution buffer). The diatoms have large contours that will bind DNA. While L6 serves as a lysis buffer and L2 as a washing buffer, and Tris EDTA (TE) to bind DNA out of diatoms. The RT-PCR was carried out to determine the levels of caspase- 3 mRNA gene expression. RT-PCR was performed with the following primers, caspase-3 forward: 5'-AGCTTCTTCAGAGGCGACTA-3' and reverse: 5'-GGACACAATACACGGGATCT-3' [15]; and glycerol-aldehyde-3-phosphate dehydrogenase (GAPDH) forward: 5'-CTCAAGATTGTCAGCAATGC-3' and reverse: 5'- CAGGATGCCCTTTAGTGGGC-3' [16]; reactions were performed using the one-step RT-PCR kit (Macrogen, Korea), GADPH was used as an internal control. Primers for RT-PCR were designed using Oligo software (Bio-Rad CFX Manager). The blood samples from treatment and control in homogenization and total RNA samples in extraction according to the instructions of the protocol. Reactions were visualized by agarose gel electrophoresis analysis. Rate threshold cycle in the calculation of the standard software. The level of expression exraction according to the instructions of the protocol. Making PCR mix: using solution (Table 1), for caspase-3 made in triplicate. Then take $5.2 \mu \mathrm{l}$ caspase-3 into each well (each well requires a $5.2 \mu \mathrm{l}$ PCR mix). Also, distribute GAPDH (as standard) into the wells, each well needs a $5.2 \mu \mathrm{l}$ PCR mix. Here, fill the samples in the wells each containing the PCR mix, caspase-3, and GAPDH, wait for $1.5 \mathrm{~h}$. Then, turn on the PCR tool and make a layout, then input the sample that has been idle for $1.5 \mathrm{~h}$ into the wells, each enter as much as $5.2 \mu \mathrm{l}$, neither with the standard (GAPDH). Next is dilution: $20 \mu$ RNA free water inserted into the new tube (tubes $1,2,3,4,5$, and 6), then the DNA template of all samples takes as much as $20 \mu$ and diluted with $20 \mu$ which had been diluted and so on up to the six tubes. Then, enter $5 \mu$ to the wells that have been made earlier, close and insert into the PCR machine, perform an initial denaturation stage of $96^{\circ} \mathrm{C}$ for $3 \mathrm{~min}$, next $95^{\circ} \mathrm{C}$ for $30 \mathrm{~s}$, next annealing $55^{\circ} \mathrm{C}$ for $30 \mathrm{~s}$ with volume contents $5+5=10 \mu 40$ times.

\section{Statistical analysis}

The data caspase-3 mRNA gene expression was statistically analyzed and the significance calculated using one-way "ANOVA" (Bonferroni) followed by Tukey's test. All numerical values were expressed as a mean \pm standard deviation and the value of $p<0.05$ was considered as statistically significant.

Fig. 1Schematic of the research process. Twenty Wistar rats were divided into 5 groups: $\mathrm{K} 0=$ no induction $\mathrm{AD}$ model and no $\mathrm{BE}$ administration; $\mathrm{K} 1=\mathrm{AD}$ induction model without $\mathrm{BE}$ administration; $\mathrm{K} 2=\mathrm{AD}$ induction model with $250 \mathrm{mg} / \mathrm{kg}$ BW BE administration; K3=AD induction model with $500 \mathrm{mg} / \mathrm{kg}$ BW BE administration; and $\mathrm{K} 4=\mathrm{AD}$ induction model with $1000 \mathrm{mg} / \mathrm{kg}$ BW BE administration. Caspase-3 mRNA expression

Table 1: Stages of PCR mix manufacturing

\begin{tabular}{lll}
\hline RT-PCR & Caspase-3 $(\times 80)$ & GAPDH $(\times 30)$ \\
\hline Master mix $=2.5 \mu \mathrm{l}$ & $200 \mu \mathrm{l}$ & $75 \mu \mathrm{l}$ \\
Free water $=2.5 \mu \mathrm{l}$ & $200 \mu \mathrm{l}$ & $75 \mu \mathrm{l}$ \\
Primer Caspase-3 F=0.1 $\mathrm{l}$ & $8 \mu \mathrm{l}$ & $3 \mu \mathrm{l}$ \\
Primer Caspase-3 R=0.1 $\mu \mathrm{l}$ & $8 \mu \mathrm{l}$ & $3 \mu \mathrm{l}$ \\
\hline
\end{tabular}

Template $=5 \mu \mathrm{l}$

RT-PCR: Real time-polymerase chain reaction 
was assessed before AD induction, 6 weeks after AD induction, and 3 weeks post-BE administration.

\section{RESULTS}

In this study, we examined the effects of MPL administration at various doses in an AD animal model. The schematic of our research strategy is shown in Fig. 1. The levels of caspase-3 mRNA at various time points throughout the analysis were evaluated. The caspase- 3 mRNA expression levels in all observation groups are summarized in Table 2

Paired t-test and one-way ANOVA (Bonferroni) showed changes in caspase- 3 mRNA expression after 6 weeks post-induction $A \beta$, and no significant differences in caspase-3 mRNA expression among all five groups before induction were observed $(p>0.05)$. At 6 weeks postinduction $A \beta$, there was a significant increase $(p<0.05)$ in caspase- 3 mRNA expression in all groups except the K0 group. There were no significant differences in the increase in caspase- 3 mRNA expression among induction groups $(p>0.05)$. At 6 weeks after induction $A \beta$, we detected increased caspase- 3 mRNA expression in the induction $A \beta$ groups, while no changes occurred in the non-induction $A \beta$ group (K0).

Paired t-test and one-way ANOVA (Bonferroni) were used to examine changes in caspase-3 mRNA expression after 3 weeks post-BE admission, and after 3 weeks of BE administration, there was a significant increase in caspase- 3 mRNA in the group without BE (placebo) compared with the levels at week 6 before BE treatment $(p<0.05)$. Notably, in all groups receiving $\mathrm{BE}$, all showed a significant decrease in caspase-3 mRNA expression compared with the levels at week 6 before BE treatment $(p<0.05)$. After 3 weeks of BE admission during the post-induction period, caspase- 3 mRNA expression decreased in all groups given BE. In comparison, in the group given the only placebo, the caspase- 3 mRNA levels continued to increase. The maximum decrease in caspase- 3 mRNA expression was observed in the $\mathrm{K} 4$ group, which received a $\mathrm{BE}$ dosage of $1000 \mathrm{mg} / \mathrm{kg}$ BW. The smallest decrease was observed in group $\mathrm{K} 2$, which received a BE dosage of $250 \mathrm{mg} / \mathrm{kg} \mathrm{BW}$.

\section{DISCUSSION}

Despite extensive investigations, the mechanism activating apoptotic pathways or neuronal degeneration in the $\mathrm{AD}$ has not been completely understood. In the present study, we showed the effects of administration of MPL extract BE on caspase- 3 mRNA expression in $A \beta$-induced AD rats. Our results show that: (i) in both $\mathrm{K} 1$ (placebo) and $\mathrm{K} 2$, K3 and K4 before MPL- detected treatment intervention experienced an increase in caspase- 3 mRNA expression at 6 weeks after induction of $A \beta$, which is similar to the result presented by cetin et al. Their research found high caspase- 3 activity levels in hippocampus, temporal, and parietal cortex in aged mice injected with $A \beta_{1-42}$ [17]. $A \beta$ has been proposed as the main factor in the $\mathrm{AD}$ pathophysiology mechanism and the major

Table 2: Caspase-3 mRNA expression in each group

\begin{tabular}{|c|c|c|c|c|c|c|}
\hline \multirow[t]{2}{*}{ Variable } & \multirow[t]{2}{*}{ Groups } & \multicolumn{5}{|l|}{ Observation time } \\
\hline & & $\begin{array}{l}\text { Before } \\
\text { induction (baseline } \\
\text { week 0) }\end{array}$ & $\begin{array}{l}6 \text { weeks after } \\
\text { induction (weeks 6) }\end{array}$ & $\begin{array}{l}3 \text { weeks post-BE } \\
\text { treatment } \\
\text { (Week 9) }\end{array}$ & $\begin{array}{l}0-6 \\
p^{*}\end{array}$ & $\begin{array}{l}6-9 \\
p\end{array}$ \\
\hline \multirow{4}{*}{$\begin{array}{l}\text { Caspase- } 3 \text { mRNA expression } \\
\text { mean } \pm \text { SD }\end{array}$} & $\mathrm{K} 0(\mathrm{n}=4)$ & $7.68(0.25)^{\mathrm{A}}$ & $7.66(0.23)^{\mathrm{A}}$ & $7.64(0.06)^{\mathrm{A}}$ & 0.900 & 0.871 \\
\hline & $\mathrm{K} 1(\mathrm{n}=4)$ & $7.65(0.07)^{A}$ & $12.69(0.16)^{\mathrm{B}}$ & $13.67(0.16)^{\mathrm{B}}$ & $<0.001$ & 0.007 \\
\hline & $K 3(n=4)$ & $7.63(0.07)^{\mathrm{A}}$ & $12.73(0.15)^{\mathrm{B}}$ & $9.23(0.18)^{\mathrm{C}}$ & $<0.001$ & $<0.001$ \\
\hline & $\mathrm{K} 4(\mathrm{n}=4)$ & $7.68(0.10)^{\mathrm{A}}$ & $12.53(0.04)^{\mathrm{B}}$ & $8.65(0.10)^{\mathrm{C}}$ & $<0.001$ & $<0.001$ \\
\hline
\end{tabular}

Values are mean \pm SD. Statistics+one-way ANOVA followed by Bonferroni post hoc test, ${ }^{*} \mathrm{p}>0.05$ versus K0, ${ }^{\mathrm{p}}<0.05$ versus K1, *p $<0.05$ versus K2, ${ }^{\mathrm{p}}<0.05$ versus K3

${ }^{*} \mathrm{p}<0.05$ versus $\mathrm{K} 4$. N=Number of rats in each group, BE: Banana extract, SDM=Standard deviation mean

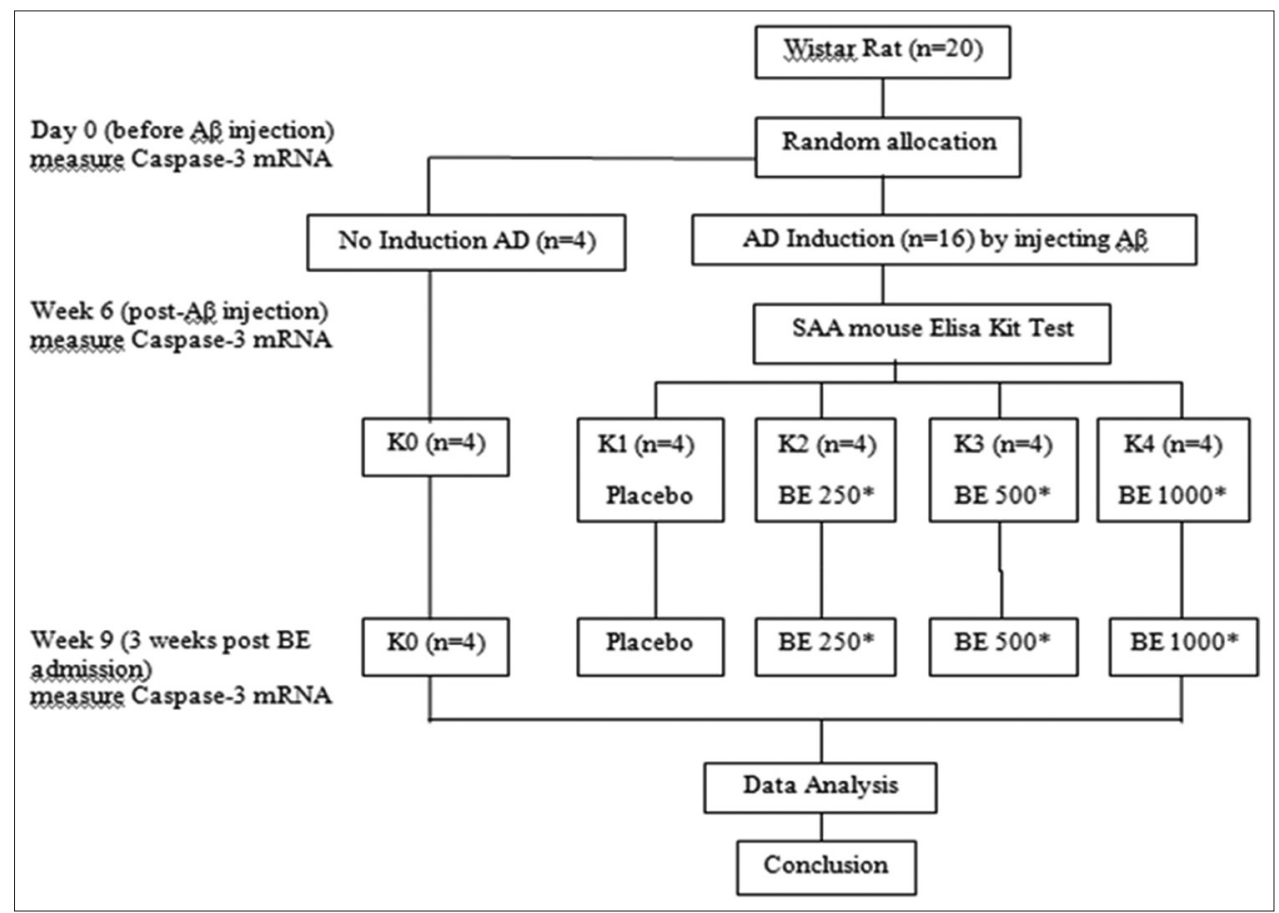

Fig. 1: Outline of research process 
component of senile plaques, is considered to play a central role in neuronal cell death (apoptosis), and has received the most attention [18]. This has been demonstrated in neurons of human and rodent brains. In patients suffering from neurodegenerative disorders such as $\mathrm{AD}, \mathrm{PD}$, and amyotrophic lateral sclerosis, there is a prominent increase in the neuronal RNA damage when compared to normal aging people [19]. Several factors that are assumed to contribute in AD pathogenesis, such as the role of key proteins, oxidative damage, mitochondrial dysfunction, and the cholinergic hypothesis [20]. The role of neuronal cell death (apoptosis) includes caspase-9 and caspase-3 [21]. Our next findings in this study are (ii) that the placebo group continued to show significantly increased caspase-3 mRNA levels for the next 3 weeks. However, in groups treated with MPL BE, we observed the opposite trend, with a significant decrease of caspase-3 mRNA expression $(p<0.05)$. The maximum decreased level of caspase- 3 mRNA expression was observed in K4, the group which received the highest dose of MPL $\mathrm{BE}$ in this study ( $1000 \mathrm{mg} / \mathrm{kg} \mathrm{BW} \mathrm{BE}$ ), and the minimum decrease was observed in group $\mathrm{K} 2$, which received $250 \mathrm{mg} / \mathrm{kg} \mathrm{BW} \mathrm{BE}$. This result is consistent with the study by Vijayakumar et al., who reported findings of flavonoid antioxidant MPL activity in mice [22]. The antioxidant activity of the extracted flavonoids from $M$. paradisiacal in rats stimulated the activities of superoxide dismutase and catalase which might be responsible for the reduced level of peroxidation products such as malondialdehyde, hydroperoxides, and conjugated dienes [22].

The authors stated that flavonoids could modulate the expression of several genes through activation of many transcription factors and act as a neuroprotection agent, were thought to work by modulating kinase proteins, and act as a kinase cascade lipid signal, such as phosphatidyl inositol-3 kinase (PI3K)/Akt pathway signal, tyrosine kinase, protein kinase $\mathrm{C}$ (PKC) and mitogen-activated protein kinase (MAPK), and PKB [23]. Activation of neuronal cell membrane receptors may result in caspase activation, enhanced calcium levels, and the generation of reactive oxygen species (ROS), both are known to contribute to the mitochondrial pathway, including B-cell lymphoma 2 (Bcl-2) proteins, high intracellular calcium levels. and ROS. On entering the cytoplasm, cytochrome c forms an apoptosomal complex with a procaspase, adenosine triphosphate, and apoptotic protease activating factor 1 (Apaf-1), an Apaf-1 [21]. The apoptotic pathway is generally characterized by various signals including mitochondrial release from proapototic molecules such as Bcl-2, ROS, high calcium and cytochrome C binds Apaf- 1 and procaspase 9 to form apoptosomes, which further activate caspase 9 nd procaspase 9 to form the apoptosome, thereby activating caspase 9. Caspase-9 activates caspase-3, ultimately leading to cell death [24]. Heo et al. used BE MPL to protect neurons from oxidative stress by neurotoxicity. The study also showed that BE MPL could reduce oxidative stress risk caused by neurodegenerative diseases, such as $\mathrm{AD}$ [22]. The $\mathrm{BE}$ possess very good radical scavenging activity and as well the largest amount of phenolic contents, which could introduce phenols as the main radical scavenger in $\mathrm{BE}$ and offering effective protection from free radicals and the antioxidant activity [25]. The difference with the previous research that they only see MPL on oxidative stress and as an antioxidant, but in this study, emphasized its effect on the expression of the caspase- 3 mRNA gene. We add the biochemical evidence showing that treatment with ethanolic extract MPL can decrease serum expression of caspase-3 mRNA in an animal model for the AD, suggesting that it may prevent cell apoptosis. Further studies are required to isolate and evaluate individual phytoconstituents in MPL for their neuroprotection potential.

\section{CONCLUSION}

Taking together, it may finally be concluded that $\mathrm{A} \beta$-induced AD causes neuron cell death, where apoptosis plays an important role in it and may be inhibited by flavonoids, may exert regulatory activities in cells through actions such as cyclin-dependent kinases, caspases, Bcl-2 family members, epidermal growth factor/epidermal growth factor receptor, phosphatidylinositol-3-kinase/Akt, MAPK, and include the inhibition of c-Jun N-terminal kinases and p38 pathways and the activation of PI3-K/
Akt, and PKC pathways in different type of cell such as neuronal, cardiac, endothelial, epithelial, hepatocytes, and macrophages. Such interactions of flavonoids with cell signaling pathways provide various beneficial effects such as improving brain function, preventing oxidative stress, preventing apoptosis, protecting against endothelial barrier dysfunction and injury, improving the cognitive function, decreasing the neurodegeneration, and stimulating endothelial NOS activity. That natural flavonoids can inhibit caspase-3 activity. Medication using MPL ethanol extract can decrease caspase-3 mRNA expression in AD rats. Suggesting that these flavonoids may be useful which leads to the rational design of non-peptidic, caspasespecific inhibitors for therapeutic use. Herbs may play a promising role in the early treatment of Alzheimer's and other conditions involving poor memory and dementia. One of the chief benefits is that they have a low side effect compared to pharmaceutical agents.

\section{ACKNOWLEDGMENT}

The authors would like to appreciate Mr. Romi Usman, Mr. Mus and Marwani in the Molecular Microbiology and Immunology Laboratory, Medical Faculty, University of Hasanuddin, Makassar, Indonesia, who helped our research.

\section{CONTRIBUTION}

The first author has carried out the research. Second, third, fourth, and fifth authors have provided study conception, the design of work, drafting of the manuscript, and critical revision.

\section{REFERENCES}

1. Aggarwal NT, Shah RC, Bennett DA. Alzheimer's disease: Unique markers for diagnosis and new treatment modalities. Indian J Med Res 2015;142:369-82.

2. Alzheimer's association. Alzheimer's disease facts and figures. Alzheimers Dement 2012;8:131-68.

3. Seshadri S, Wolf PA. The Lifetime risk of stroke and dementia: Current concepts, and estimates from the Framingham Study. Lancet Neurol 2007;6:1106-14

4. Rubinsztein DC. The roles of intracellular protein-degradation pathways in neurodegeneration. Nature 2006;443:780-6.

5. Arif NS, Kasi, Devi P. Botanics: A potential source of new therapies for Alzheimer's disease? Botanics 2014;4:11-26.

6. Earnshaw WC, Martins LM, Kaufmann SH. Mammalian caspases: Structure, activation, substrates, and functions during apoptosis. Ann Rev Biochem 1999;68:383-424.

7. Ashkenazi A, Dixit VM. Death receptors: Signaling and modulation. Science 1998;281:1305-8.

8. Wolf BB, Schuler M, Echeverri F, Green DR. Caspase-3 is the primary activator of apoptotic DNA fragmentation via DNA fragmentation factor-45/inhibitor of caspase-activated DNase inactivation. J Biol Chem 1999;274:30651-6.

9. Kuida K, Zheng TS, Na S, Kuan C, Yang D, Karasuyama H, et al. Deceased apoptosis in the brain and premature lethality in CPP32deficient mice. Nature 1996;384:368-72.

10. Khan SM, Cassarino DS, Abramova NN, Keeney PM, Borland MK, Trimmer PA, et al. Alzheimer's disease cybrids replicate b-amyloid abnormalities through cell death pathways. Ann Neurol 2000;48:148-55.

11. Commenges D, Scotet V, Renaud S, Jacqmin-Gadda H, BarbergerGateau P, Dartigues JF. Intake of flavonoids and risk of dementia. Eur J Epidemiol 2000;16:357-63.

12. Ittiyavirah S, Anurenj DA. Adaptogenic studies of acetone extract of Musa paradisiaca L. fruit peels in albino Wistar rats. Int J Nutr Pharm Neurol Dis 2014;4:88-94.

13. Kamelia E, Miko H, Karo M, Pertiwi S, Kaelan C, Islam AA, et al. Beta amyloid peptide role in animal modeling trial of Alzheimer's disease. Int J Sci Basic Appl Res 2016;28:90-9.

14. Hatta M, Smits HL. Detection of Salmonella typhi by nested polymerase chain reaction in blood, urine, and stool samples. Am J Trop Med Hyg 2007;76:139-43

15. Cai Y, Li J, Yang S, Li P, Zhang X, Liu H. CIBZ, a Novel BTB Domaincontaining protein, is involved in mouse spinal cord injury via mitochondrial pathway independent of p53 gene. PLoS One 2012; 7:e33156.

16. Cecilia KZ, Mona-Lisa S, Söder O. The high mobility group box chromosomal protein 1 is expressed in the human and rat testis where it 
may function as an antibacterial factor. Hum Reprod 2006;21:2801-9.

17. Cetin F, Yazihan N, Dincer S, Akbulut KG. The effect of intracerebroventricular injection of beta amyloid peptide (1-42) on caspase 3 activity, lipid peroxidation, nitrit oxide and NOS expression in young adult and aged rat brain. Turk Neurosurg 2013;23:144-50.

18. Vauzour D. Dietary polyphenols as modulators of brain functions: Biological actions and molecular mechanisms underpinning their beneficial effects. Oxid Med Cell Longev 2012;2012:914273.

19. Nunomura A, Moreira PI, Castellani RJ, Lee HG, Zhu X, Smith MA, Perry G. Oxidative damage to RNA in aging and neurodegenerative disorders. Neurotox Res 2012;22:231.

20. Kiranjit K, Rajneet K, Manjinder K. Review Article: Recent advances in Alzheimer's disease: Cause and treatment. Int J Pharm Pharm Sci 2016;8:8-15
21. Hengartner MO. The biochemistry of apoptosis. Nature 2000;407:770-6.

22. Vijayakumar S, Presannakumar G, Vijayalakshmi N. Antioxidant activity of banana flavonoids. Fitoterapia 2008;79:279-82.

23. Hwang SL, Yen GC. Modulation of Akt, JNK, and p38 activation is involved in citrus flavonoid-mediated cytoprotection of PC12 cells challenged by hydrogen peroxide. J Agric Food Chem 2009;57:2576- 82.

24. Friedlander R. Apoptosis and caspases in neurodegenerative diseases. N Engl J Med 2003;348:1365-75.

25. Bashir AA, Khamsah SM, Muhammad A, Mahadeva Rao US, Than Z. Phitochemical screening, antioxidant activity of pure syringing in comparison to various solvent extracts of Musa paradisiacal (Banana) (fruit and flower) and total phenolic content. Int J Pharm Pharm Sci $2015 ; 7: 242-7$ 